\title{
LITERATURE REVIEW GAMBARAN ASUHAN KEPERAWATAN PADA PASIEN GANGGUAN PERSEPSI SENSORI ; HALUSINASI PENDENGARAN DENGAN MENGGUNAKAN TERAPI KOGNITIF
}

\author{
Apri Danu Pangestu ${ }^{1}$ Christina Trisnawati Setiawan ${ }^{2}$ Roni Purnomo ${ }^{3}$ \\ Politeknik Yakpermas Banyumas, Diploma III Keperawatan ${ }^{\mathbf{1 2 3}}$ \\ Email:apridanu@gmail.com ${ }^{123}$
}

\begin{abstract}
ABSTRAK
Latar belakang : Menurut WHO pada tahun 2017 terdapat \pm 450 juta penderita gangguan jiwa didunia termasuk skizofernia. Tingginya angka halusinasi perlu solusi dari perawat dengan melakukan tindakan asuhan keperawatan untuk pasien gangguan persepsi sensori : halusinasi pendengaran. Terapi kognitif mengacu pada pemrosesan informasi serta perilaku seseorang yang depresif. Penatalaksanaan halusinasi pendengaran salah satunya dengan terapi kognitif, individu diarahkan agar dapat berfikir lebih logis, sehingga individu mampu mengidentifikasi pikiran yang muncul sebagai sebuah gejala psikologis yang dialamin, bukan suatu hal fakta atau realita yang sedang terjadi, sehingga frekuensi halusinasi dapat turun Tujuan : Untuk mengetahui tentang gambaran tentang tindakan asuhan keperawatan pada pasien halusinasi pendengaran terapi kognitif. Metode : Penelitian deskriptif hanya menggambarkan atau memaparkan variable yang diteliti tanpa menganalisa hubungan antar variable. Hasil : Pada penelitian literature review ini didapatkan hasil terjadinya penurunan frekuensi halusinasi Tn. A dari 5 kali sehari menjadi 2 kali sehari, sedangkan pada Ny.Y tidak ditemukan adanya penurunan frekuensi halusinasi dengan frekuensi halusinasi tetap 4 kali dalam sehari. Kesimpulan : Adanya pengaruh terapi kognitif terhadap penurunan frekuensi halusinasi pada pasien halusinasi pendengaran. Terapi kognitif dapat digunakan sebagai pengobatan non-farmakologi bagi pasien dengan halusinasi pendengaran untuk menurunkan frekuensi halusinasi pendengaran.
\end{abstract}

Kata kunci : Gangguan Persepsi Sensori, Terapi Kognitif, Halusinasi Pendengaran Studi literatur : 22 (2010-2021)

\section{ABSTRACT}

Background: According to WHO in 2017 there were \pm 450 million people with mental disorders in the world including schizophrenia. The high number of hallucinations needs a solution from nurses by taking nursing care actions for patients with sensory perception disorders: auditory hallucinations. Cognitive therapy refers to the information processing and behavior of a person who is depressed. One of the management of auditory hallucinations is cognitive therapy, individuals are directed to be able to think more logically, so that individuals are able to identify thoughts that appear as a psychological symptom experienced, not a fact or reality that is happening, so that the frequency of hallucinations can decrease Objective: To find out about the description of nursing care actions in patients with cognitive therapy auditory hallucinations. Methods: Descriptive research only describes or describes the variables studied without analyzing the relationship between variables. Results: In this literature review, it was found that Mr. A's hallucinations frequency decreased from 5 times a day to 2 times a day, while Mrs. Y did not find a decrease in the frequency of hallucinations with the hallucinations frequency remaining 4 times $a$ day. Conclusion: There is an effect of cognitive therapy on decreasing the frequency of hallucinations in patients with auditory hallucinations. Cognitive therapy can be used as a nonpharmacological treatment for patients with auditory hallucinations to reduce the frequency of auditory hallucinations

Keyword: Sensory perception disorder, Cognitive Therapy, Hearing Hallucinations Study literature : 22 (2010-2021)

\section{PENDAHULUAN}

Sehat yaitu kesatuan antara raga dengan jiwa yang harus terus diupayakan secara maksimal pada setiap individu. Untuk tetap dalam situasi kondisi sehat jiwa maka 
seseorang harus mampu beradaptasi dengan perubahan yang ada dilingkungan sekitarnya, sehingga individu tetap bahagia dan semangat dalam menjalani hidup. Hal ini seperti yang dijelaskan dalam undang-undang republik indonesaia nomor 18 th 2014 tentang kesehatan jiwa bahwa keadaan dimana individu mampu berkembang secara fisik, mental, spiritual, serta sosial sehingga individu dapat memahami kemapuan yang dimilikinya, mampu mengatasi tekanan, dan memberikan manfaat untuk komunitasnya (Pusat Data dan Informasi Kementrian Kesehatan RI, 2019).

Menurut WHO pada tahun 2017 terdapat \pm 450 juta penderita gangguan jiwa didunia termasuk skizofernia. Berdasarkan survey yang dilakukan pada tahun 2017 oleh Institute Health Metrics and Evaluation, jenis gangguan jiwa yang sering diderita penduduk di indonesia diantaranya adalah depresi, cemas, skizofernia, bipolar, gangguan perilaku, autism, gangguan perilaku makan, dan cacat intelektual, Attention Deficit Hypertactivity Disorder. Riset Kesehatan Dasar dan Kementrian Kesehatan Republik Indonesia (2018), menyatakan penderita skizofernia meningkat dari yang awal 2013 hanya sejumlah $1,7 \%$ menjadi $7 \%$ pada tahun 2018 (HIMPSI, 2020). Riskesdas (2018) juga menyatakan setidaknya ada $8,7 \%$ ART (Anggota Rumah Tangga) dengan gangguan jiwa skizofernia di Jawa Tengah. (Pusat Data dan Informasi Kementrian Kesehatan RI, 2019).

Pada rehabilitasi psikososial akan dilakukan terapi kognitif pada pasien skizofernia (Hafifah et al., 2018). Terapi kognitif mengacu pada pemrosesan informasi serta perilaku seseorang yang depresif. Pada terapi ini individu akan diarahkan agar dapat berfikir lebih logis, sehingga individu mampu mengidentifikasi pikiran yang muncul sebagai sebuah gejala psikologis yang dialamin, bukan suatu hal fakta atau realita yang sedang terjadi (Susana et al., 2015). Terapi kognitif individu di edukasi untuk mengontrol ganguan persepsi pikiran yang dialami dengan mempertimbangkan faktor pencetus dalam perkembangan dan menetapnya gangguan perasaan yang dialami oleh klien (Noprianti, 2019).

Terapi kognitif adalah bertujuan untuk memberikan perkembangan kognitif untuk klien memahami kebiasaaan atau perilaku dan mampu memproses serta memahami informasi yang diberikan. Terapi kognitif berusaha mengurangi kesalahpahaman klien dan membantunnya mempelajari bermacam cara yang berbeda dan lebih realitstis untuk memproses dan menguji informasi (Palmer Stephen dalam (Noprianti, 2019)

Menurut Yusuf (2015), terapi kognitif terdiri atas 9 sesi, yang masing- masing sesi dilaksanakan secara terpisah. Setiap sesi berlangsung selama 30-40 menit dan membutuhkan konsentrasi tinggi. Sesi tersebut yaitu terdiri dari :

Sesi I : Ungkap pikiran otomatis.

Sesi II : Menyatakan alasan

Sesi III: Tanggapan terhadap pikiran otomatis

Sesi IV: Menuliskan

Sesi V : Penyelesaian masalah

SesiVI,VII,VIII:Manfaat

tanggapan,ungkaphasil dan membuat buku harian

Sesi IX : Sistem dukungan 


\section{METODE PENELITIAN}

Jenis penelitian yang
digunakan adalah penelitian deskriptif, waktu penelitian 1 desember 2020 - 30 juni 2021. Jenis

menggunakan metode penelitian deskriptif. Metode penelitian deskriptif ini merupakan suatu cara yang digunakan untuk mencari unsur, ciri, sifat tentang fenomena. Metode ini dimulai dengan pengumpulan data, dianalisi dan dilakukan penginterprestasiannya. Dalam pelaksanaan penelitian deskriptif ini dilakukan dengan: teknik survey, studi kasus, studi komparatif, studi tentang waktu dan gerak, analisis tingkah laku, dan analisis dokumenter.

Metode desktriptif ini adalah untuk mendapatkan gambaran secara realita dan obyektif terhadap sesuatu kondisi tertentu yang sedang terjadi dalam kelompok masyarakat. Permasalahan tersebut dapat berupa berupa kasus tunggal, kasus banyak, perbandingan atau hubungan (Imron, 2014).

Penelitian deskriptif hanya menggambarkan atau memaparkan variable yang diteliti tanpa menganalisa hubungan antar variable (Dharma, 2013). Dalam ilustrasi penelitian studi kasus ini dilakukan dengan tujuan memberikan asuhan keperawatan pada pasien yang memiliki gangguan persepsi sensori : halusinasi pendengaran dengan terapi kognitif.

Fokus studi adalah kajian utama dari masalah yang akan ditunjukan titik acuan studi kasus. Fokus studi kasus yang akan dikaji terapi kognitif pada pasien halusinasi pendengaran.
Instrumen penelitian adalah perlengkapan yang akan digunakan untuk mengumpulkan data saat melakukan penelitian (Notoadmojo, 2010). Instrumen yang akan dipakai kali ini adalah alat untuk menulis, lembar cheklist, dan lembar wawancara.

Tujuan penelitian dilakukan bertujuan agar dapat mengetahui tentang gambaran tentang tindakan asuhan keperawatan pada pasien halusinasi pendengaran terapi kognitif.

\section{HASIL DAN PEMBAHASAN}

Penelitian dilakukan pada tanggal 1 desember 2020 - 30 juni 2021 kepada 2 responden yaitu pada Tn.A sebagai responden 1 dan Ny.Y sebagai responden 2. Data ini didapatkan melalui observasi yang dilakukan oleh Nur Azkia pada Karya Tulis Ilmiah dengan judul "Penerapan Terapi Kgnitif Pada Pasien Gangguan Jiwa Dengan Halusinasi Pendengeran Terhadap Penurunan Frekuensi Halusinasi di RPSDM Martani Cillacap".

Hasil penelitian yang dilakukan menyebutkan bahwa Tn.A masuk ke Rumah Sakit Martani dengan kondisi bingung dan mengatakan mendengar suara dan bisikan anak kecil lalu ada yang menyuruhnya untuk memecahakan barang dan gelisah. Tn.A memiliki riwayat patah hati selama kontrak kerja semenjak saat itu Tn.A mengalami halusinasi, Tn.A juga pernah dirawat selama 2 minggu di Rumah Sakit Jiwa Banyumas 3 tahun yang lalu, namun pengobatan yang dijalani tidak berhasil. Tn.A juga mengalami putus obat selama 1 minggu karena merasa sudah sembuh. Hasil observasi mengatakan pasien merasa minder 
dan malu dengan tetangganya karena sudah pernah dirawat di umah Sakit jiwa. Saat di lingkungan pasien mengatakan jarang berkomunikasi dengan pasien lain, pasien lebih suka dirumah dan malu untuk berinteraksi dengan orang lain. Tn.A juga jarang beribadah dengan alasan malas. Saat dilakukan pengkajian didapatkan gigi Tn.A yang berwarna kuning dengan mulut berbau, kulitnya pun kusam dan kering disertai gatal-gatal. Pada pengkajian aktivitas motorik pasien tampak memiliki pandangan kosong. Tn.A mengatakan saat mendengar suara anak kecil ia merasa kasihan dan membuat ia menangis mengakibatkan ia marah dan memecahkan barang, suara itu muncul secara tiba-tiba. Tn.A mengatakan mengetaui cara menghilangkan suara-suara tersebut dengan menghardik tetapi pikiranpikiran tersebut belum bisa hilang.

Sedangkan Ny.Y masuk ke Martani Cilacap dengan keadaan depresi, trauma, gelisah, suka marah-marah dan mendengar bisikan yang menyuruhnya untuk memecahkan piring dan gelas. Ny.Y memiliki riwayat trauma karena melihat adiknya di aniaya dan sering disebut "kawin cerai" oleh kakaknya yang membuat Ny.Y takut. Sejak saat itu Ny.Y sering marah-marah, melamun dan sering mendengar suara yang menyuruhnya untuk memecahkan piring dan gelas, Ny.Y pernah di rawat di RSJ Klaten dan RSJ Magelang masing-masing selama 1 tahun, namun selama dirawat Ny.Y kurang patuh saat diharuskan meminum obat.Ny.Y memiliki riwayat gastritis dan saat dilakukan pengkajian dalam garis keturunan terdapan anggota yang mengalami gangguan jiwa yaitu adiknya. Hasil pengkajian dalam konsep diri juga menyatakan pasien merasa minder dan malu dengan tetangganya karena sudah pernah dirawat di Rumah Sakit Jiwa. Pasien jarang berkomunikasi dengan pasien lain, lebih suka menyendiri dikamar dan malu untuk berinteraksi, pasien jarang beribadah dengan alasan malas. Ny.Y memiliki rambut kotor dan terdapat kutu, gigi kuning dan mulut berbau serta memiliki kulit yang kusam, kering dan mengalami gatal gatal. Saat dilakukan wawancara pasien nampak memiliki pandangan kosong. Ny.Y seringkali mendengar suara "kawin cerai" muncul secara tiba-tiba sehingga membuatnya menjadi marah dan memecahkan piring/gelas. Ny.Y mengetahui cara menghilangkan suaa dengan menghardik tetapi tidak pernah digunakan saat mendengar suara-suara tersebut.

Berdasarkan data diatas maka dapat disimpulkan bahwa kedua responden sama-sama mengalami gangguan persepsi sensori halusinasi. Halusinasi adalah perubahan sensori dimana pasien merasakan sensasi yang tidak ada berupa suara, penglihatan, pengecapan, dan perabaan (Sulistyowati \& Purnomo, 2021). Sesuai manifestasi klinis menurut Dermawan (2013) yang menyebutkan bahwa pasien halusinasi pendengaran memiliki gejala seperti mendengar adanya suara dan kebisingan, mendengar adanya suara yang memerintahkan suatu hal dan merasakan takut atau gembira saat mengalami halusinasi. Untuk tahapan halusinasi yang dialami oleh kedua responden adalah halusinasi tahap ke 3 (tiga), 
dinyatakan tahap ketiga karena pada tahapan halusinasi ini perilaku yang dapat teramati adalah berupa pasien halusinasi memilih untuk mengikut arahan yang diberi oleh halusinasinya dari pada menolak, sulitnya dalam menjalin hubungan social dengan orang lain. Kedua responden juga sama-sama pernah menjalani perawatan di Rumah Sakit Jiwa dan memiliki riwayat masalah putus obat meskipun dengan alasan berbeda, responden A putus obat selama 1 minggu karena merasa sudah sembuh sedangkan responden B karena tidak patuh saat diharuskan minum obat, mengakibatkan proses pengobatan tidak berhasil. Berdasarkan penelitian yang dilakukan oleh Adelufosi menunjukan bahwa kepatuhan minum obat berpengaruh terhadap kambh dan kualitas hidup pasien, pernyataan ini juga didukung oleh penelitian yang dilakukan oleh Mubin \& Liviana saat hasil uji korelasi ditketahui bahwa kepatuhan minum obat pasien memiliki hubungan yang signifikasn dengan kekambuhan pasien, dengan arah hubungan terbalik yang berarti bahwa semakin patuh pasien dalam minum obatmaka menurunkan kekambuhan pasien. Menurut Simanjuntak bahwa pasien mengalami ketidak patuhan minum obat dan kambuh disebabkan karena adanya masalah lingkungan dan dukungan keluarga dalam merawat pasien (Mubin et al., 2019).

Untuk pemicu halusinasi tersebut juga berbeda Tn.A mengalami halusinasi dikarenakan patah hati sedangkan Ny.Y mengalami halusinasi dikarenakan sering dikata-katai "kawin cerai" oleh kakaknya dan trauma yang dialami saat melihat adiknya yang dianiaya hingga berdarah. Dalam isi halusinasi masing masing responden memiliki kesamaan yaitu adanya suara yang memerintahkan responden untuk memecahkan barang. Menurut Nyumirah (2013) halusinasi pendengaran paling sering terjadi Ketika klien mendengaar suara-suara, suara tersebut dianggap terpisah dari pikiran klien sendiri, isi dari suara tersebut seperti mengancam dan menghina, sering kali suara tersebut memerintah klien untuk melakukan tindakan yang akan melukai klien atau orang lain. Pernyataan ini juga didukung oleh Maharani (2019) didapatkan data pasien yang sering mendengar bisikan-bisikan yang menyuruhnya untuk marah-marah, tertawa sendiri, berbicara nglantur, dan pasien lebih senang menyendiri dan bersikap pemalu (Mislika, 2020).

Pada hasil pengkajian konsep diri Responden sama-sama mengalami harga diri rendah yaitu malu untuk berinteraksi dengan orang lain, namun Ny.Y saat mengalami masalah memilih untuk bercerita dengan ayahnya sedangkan Tn.A hanya memendamnya sendiri. Menurut Stuart dan Laraia harga diri rendah adalah salah satu factor presipitasi yang menyebabkan pasien mengalami gangguan persepsi sensori halusinasi. Saat pasien mengalami harga diri rendah ia akan merasa tidak mampu, putus asa, tidak percaya diri, dan merasa gagal, kemampuan sosialisasi masien menjadi menurun sehingga mengakibatkannya terjadi halusinasi (Dalami et al., 2009).

Dari data pengkajian diatas bisa diperoleh beberapa masalah, tidak hanya fokus pada Halusinasi pendengaran, dengan Analisa data sebagai berikut : 


\section{Pasien Tn A}

\begin{tabular}{|c|c|c|}
\hline No & Problem & Tanda Gejala \\
\hline 1 & $\begin{array}{l}\text { Gangguan } \\
\text { Persepsi } \\
\text { Sensori : } \\
\text { Halusinasi } \\
\text { Pendengan }\end{array}$ & $\begin{array}{l}\text { Do : } \\
\text { pasien } \quad \text { tampak } \\
\text { bingung } \\
\text { gelisah dan } \\
\text { Ds : pasien } \\
\text { mengatakan } \\
\text { mendengar } \\
\text { suara/bisikan } \\
\text { anak kecil, ada } \\
\text { yang } \\
\text { menyuruhnya } \\
\text { memecahkan } \\
\text { barang. }\end{array}$ \\
\hline 2 & Isolasi Sosial & $\begin{array}{l}\text { Do : pasien lebih } \\
\text { suka dirumah dan } \\
\text { malu untuk } \\
\text { berinteraksi } \\
\text { dengan orang lain } \\
\text { Ds :, pasien } \\
\text { mengatakan } \\
\text { jarang } \\
\text { berkomunikasi } \\
\text { dengan pasien } \\
\text { lain }\end{array}$ \\
\hline 3 & $\begin{array}{l}\text { Resiko perilaku } \\
\text { kekerasan }\end{array}$ & 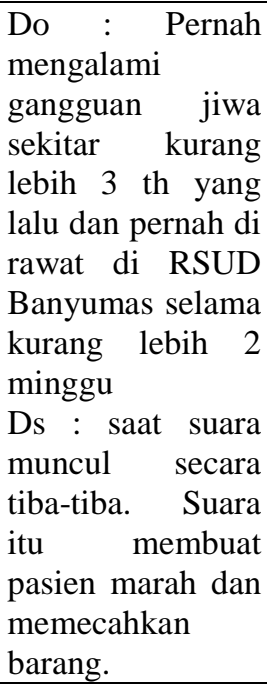 \\
\hline 4 & $\begin{array}{l}\text { Gangguan } \\
\text { Konsep diri : } \\
\text { Harga diri } \\
\text { rendah }\end{array}$ & $\begin{array}{l}\text { Do: tampak } \\
\text { pandangan mata } \\
\text { kosong } \\
\text { Ds : pasien } \\
\text { merasa minder } \\
\text { dan malu dengan } \\
\text { tetangganya } \\
\text { karena sudah } \\
\text { pernah di rawat di } \\
\text { Rumah Sakit Jiwa }\end{array}$ \\
\hline 5 & $\begin{array}{l}\text { Defisit } \\
\text { Perawatan Diri }\end{array}$ & $\begin{array}{l}\text { Do : terlihat gigi } \\
\text { kuning, mulut }\end{array}$ \\
\hline
\end{tabular}

\begin{tabular}{|c|c|c|}
\hline & & $\begin{array}{l}\text { berbau, kulit } \\
\text { kusam, kering } \\
\text { dan gatal gatal } \\
\text { Ds : }\end{array}$ \\
\hline 6 & $\begin{array}{l}\text { Ketidefektifan } \\
\text { Manajemen } \\
\text { Kesehatan }\end{array}$ & $\begin{array}{l}\text { Do: pasien masih } \\
\text { mengalami } \\
\text { halusinasi } \\
\text { Ds : pasien } \\
\text { mengetahui cara } \\
\text { menghilangkan } \\
\text { suara-suara } \\
\text { dengan cara } \\
\text { menghardik tetapi } \\
\text { suara tersebut } \\
\text { belum bisa hilang } \\
\text { dari kepalanya }\end{array}$ \\
\hline 7 & Ketidakpatuhan & $\begin{array}{l}\text { Do : pasien tidak } \\
\text { meminum obat } \\
\text { selama } 1 \text { minggu } \\
\text { Ds : pasien } \\
\text { mengatakan } \\
\text { sudah sembuh }\end{array}$ \\
\hline
\end{tabular}

halusinasi pendengaran, dengan causa isolasi sosial dan efek yang bisa ditimbukan oleh core problem resiko perilaku kekerasan

Pasien Ny. Y

\begin{tabular}{|c|c|c|}
\hline No & Problem & Tanda Gejala \\
\hline 1 & $\begin{array}{l}\text { Gangguan } \\
\text { Persepsi } \\
\text { Sensori : } \\
\text { Halusinasi } \\
\text { Pendengan }\end{array}$ & $\begin{array}{l}\text { Do : pasien } \\
\text { tampak gelisah } \\
\text { Ds : pasien } \\
\text { mengatakan } \\
\text { mendegar suara- } \\
\text { suara seperti } \\
\text { "Kawin Cerai" } \\
\text { secara berulang } \\
\text { yang } \\
\text { membuatnya } \\
\text { takut. Muncul } \\
\text { secara tiba tiba } \\
\text { dan membuat } \\
\text { pasien menjadi } \\
\text { marah dan } \\
\text { memecahkan } \\
\text { piring /gelas. }\end{array}$ \\
\hline 2 & Isolasi Sosial & \begin{tabular}{l}
\multicolumn{1}{c}{ Do : pasien } \\
lebih suka \\
menyendiri dan \\
malu untuk \\
berinteraksi \\
dengan orang lain \\
$\quad$ Ds : pasien \\
mengatakan \\
jarang
\end{tabular} \\
\hline
\end{tabular}




\begin{tabular}{|c|c|c|}
\hline & & $\begin{array}{l}\text { berkomunikasi } \\
\text { dengan pasien } \\
\text { lain dan lebih } \\
\text { suka menyendiri } \\
\text { dikamar }\end{array}$ \\
\hline 3 & $\begin{array}{l}\text { Resiko } \\
\text { Perilaku } \\
\text { Kekerasan }\end{array}$ & $\begin{array}{l}\text { Ds : Pernah } \\
\text { mengalami } \\
\text { gangguan jiwa } \\
\text { sebelumnya, dan } \\
\text { pernah di rawat di } \\
\text { RSJ Klaten 1 } \\
\text { tahun dan RSJ } \\
\text { Magelang 1 } \\
\text { tahun. } \\
\text { Do : pasien } \\
\text { mengatakan saat } \\
\text { suara muncul } \\
\text { secara tiba-tiba. } \\
\text { Suara itu } \\
\text { membuat pasien } \\
\text { marah dan } \\
\text { memecahkan } \\
\text { barang. }\end{array}$ \\
\hline 4 & $\begin{array}{l}\text { Gangguan } \\
\text { Konsep diri : } \\
\text { Harga diri } \\
\text { rendah }\end{array}$ & $\begin{array}{l}\text { Do : nada } \\
\text { berbicara lirih } \\
\text { dan tampak } \\
\text { pandangan mata } \\
\text { kosong } \\
\text { Ds : pasien } \\
\text { merasa minder } \\
\text { dan malu dengan } \\
\text { tetangganya } \\
\text { karean sudah } \\
\text { pernah di rawat di } \\
\text { Rumah Sakit } \\
\text { Jiwa. pasien suka } \\
\text { menyendiri } \\
\text { dikamar dan malu } \\
\text { untuk berinteraksi } \\
\text { dan malu untuk } \\
\text { berinteraksi } \\
\text { dengan orang lain }\end{array}$ \\
\hline 5 & $\begin{array}{l}\text { Defisit } \\
\text { Perawatan } \\
\text { Diri }\end{array}$ & $\begin{array}{l}\text { Do : rambutnya } \\
\text { kotor, terdapat } \\
\text { kutu, gigi kuning } \\
\text { dengan mulut } \\
\text { berbau, kulit } \\
\text { kusam,kering, } \\
\text { dan gatal-gatal } \\
\text { Ds : }\end{array}$ \\
\hline 6 & $\begin{array}{l}\text { Ketidefektifa } \\
\text { n Manajemen } \\
\text { Kesehatan }\end{array}$ & $\begin{array}{l}\text { Do: pasien masih } \\
\text { mengalami } \\
\text { halusinasi } \\
\text { Ds : pasien } \\
\text { mengetahui cara } \\
\text { menghilangkan } \\
\text { suara-suara } \\
\text { dengan cara }\end{array}$ \\
\hline
\end{tabular}

\begin{tabular}{|r|l|l|}
\hline & & $\begin{array}{l}\text { menghardik tetapi } \\
\text { tidak pernah } \\
\text { diterapkan saat } \\
\text { pikiran-pikiran } \\
\text { tersebut muncul }\end{array}$ \\
\hline 7 & $\begin{array}{l}\text { Ketidakpatuh } \\
\text { an }\end{array}$ & $\begin{array}{l}\text { Do : pasien susah } \\
\text { untuk meminum } \\
\text { obat/kepatuhan } \\
\text { minum obat } \\
\text { kurang. } \\
\text { Ds : pasien } \\
\text { mengatakan } \\
\text { halusinasi masih } \\
\text { sering muncul }\end{array}$ \\
\hline
\end{tabular}

Ny. Y dengan core problem halusinasi pendengaran, dengan causa isolasi sosial dan efek yang bisa ditimbukan oleh core problem adalah pasien mengalami resiko perilaku kekerasan.

Sesuai dengan pohon masalah halusinasi menurut Trisno (2012) yang menyebutkan bahwa halusinasi merupakan core problem dengan causa isolasi social mengakibatkan (effect) resiko perilaku kekerasan. Dan didukung oleh pernyataan Stuart dan Laria bahwa saat kemampuan sosialisasi pasien menurun maka akan menimbulkan terjadinya halusinasi.

Dari masalah yang timbul baik pada Tn A maupun Ny Y harus diselesaikan berdasarkan prioritas masalah. Menurut Kozier (2010) Perawat dapat menangani diagnosa dengan prioritas tinggi dan kemudian melakukan penanganan untuk diagnosa dengan prioritas rendah. Setelah itu, pasien biasanya mengali beberapa masalah, perawat sering kali menangani lebih dari satu diagnosis pada waktu yang terbatas. Prioritas diagnosa juba bisa berubah seiring dengan respon pasien yang berubah, masalah dan terapi (Jannah, 2019).

Diagnosa utama yang dapat di ambil adalah diagnosa halusinasi pendengaran. Menurut Wartonah 
dan Tarwoto (2016) disebutkan bahwa salah satu cara untuk menentukan diagnose utama adalah mengikuti hirarki maslow, dalam hirarki maslow permasalahan halusinasi sendiri berkaitan dengan keamanan dan kenyamanan (hirarki maslow kedua) seseorang. Selain itu menurut Griffith-Kenney Cristensen saat menentukan prioritas masalah salah satunya adalah karena bersifat mengancam bagi kehidupan dan kesehatan klien.

Setelah peneliti telaah lagi ke hasil pengkajian yang dilakukan, ditemukan sebenarnya peneliti dapat menarik beberapa diagnosa selain dari yang sudah diambil seperti :

a. Pada kasus Tn.A

1) Gangguan Persepsi Sensori : Halusinasi Pendengan

2) Isolasi Sosial

3) Resiko perilaku kekerasan

4) Gangguan Konsep diri : Harga diri rendah

5) Defisit Perawatan Diri

6) Ketidefektifan Manajemen Kesehatan

7) Ketidakpatuhan

b. Pada kasus Ny.Y

1) Gangguan Persepsi Sensori : Halusinasi Pendengan

2) Isolasi Sosial

3) Resiko perilaku kekerasan

4) Gangguan Konsep diri : Harga diri rendah

5) Defisit Perawatan Diri

6) Ketidefektifan Manajemen Kesehatan

7) Ketidakpatuhan

Pada intervensi dan implementasi dengan diagnosa halusinasi pendengaran yang dilakukan sesuai dengan kasus di atas, peneliti sebelumnya melakukan implementasi intervensi selama 4 hari dengan jeda 1 hari saat sudah 2 hari berjalan.. Pada Tn.A dilakukan mulai tanggal 15-19 april 2019. Pada Ny.Y dilakukan mulai tanggal 18-24 april 2019. Dalam asuhan keperawatan disebutkan peneliti melakukan beberapa implementasi. Pada hari pertama, Melakukan bina hubungan saling percaya kepada pasien, Melakukan kontrak waktu dan memperkenalkan diri, Mengidentifikasi jenis, isi, frekuensi, waktu, situasi dan respon halusinasi pendengaran (Sp1), Menjelaskan cara mengontrol halusinasi dengan terapi kognitif. Pada hari kedua melakukan terapi kognitif yang pertama dari sesi I sampai VIII. Pada hari ketiga, melatih Kembali terapi kognitif dari sesi I sampai VIII. Pada hari ke empat, melatih Kembali terapi kognitif dari sesi I sampai VIII.

Pada implementasi hari pertama, responden 1 mengatakan sudah sedikit memahami tentang cara penerapan terapi kognitif, namun belum memahami semua sesi hanya sesi I dan II yang mampu dilakukan oleh responden saat hari pertama, responden belum bisa menerapkannya secara mandiri, karena masih bingung di sesi ke III yaitu tanggapan terhadap pikiran otomatis, responden bingung cara menghilangkan pikiran negatifnya dan belum memahami tentang cara membuat tanggapan rasionalnya. Frekuensi halusinasi pada hari pertama masih sama yaitu 5 kali dalam satu hari, dengan waktu pagi $2 \mathrm{x}$, siang $2 \mathrm{x}$ dan malam 1x. Dengan demikian masih belum ada perubahan antara sebelum dan sesudah diberikan terapi kognitif. Sedangkan responden 2 mengatakan 
belum mampu memahami tentang cara penerapan terapi kognitif, hanya mampu memahami Sesi I yang mampu dilakukan oleh responden saat hari pertama, dilihat dari respon setelah diberi terapi terlihat bingung dan tidak mengerti dengan apa yang telah di ajarkan, dan saat ditanya responden hanya menjawab seperlunya. Frekuensi halusinasi pada hari pertama masih sama yaitu 4 kali dalam satu hari, dengan waktu siang $2 \mathrm{x}$, sore $1 \mathrm{x}$, malam 1x. Dengan demikian masih belum ada perubahan antara sebelum dan sesudah diberikan terapi kognitif.

Hari kedua implementasi, responden 1 mengatakan sudah memahami tentang cara penerapan terapi kognitif. Responden mampu menuliskan pikiran negatifnya dengan menggunakan metode 3 kolom dan mampu membuat tanggapan rasionalnya serta membacanya saat halusinasi muncul. Frekuensi halusinasi pada hari kedua berkurang menjadi $3 \mathrm{x}$ selama 24 jam, dengan waktu siang 2x dan malam 1x. Dengan demikian ada perubahan antara sebelum dan sesudah diberikan terapi kognitif.

Responden 2 mengatakan hanya sedikit memahami tentang cara penerapan terapi kognitif dan masih bingung karena tidak mengerti cara membuat tanggapan rasional saat pikiran negatifnya muncul, dan malas untuk membuat buku harian. Frekuensi halusinasi pada hari kedua masih sama yaitu $4 x$ selama 24 jam, dengan waktu siang $2 \mathrm{x}$, sore $1 \mathrm{x}$ dan malam 1x. Dengan demikian masih belum ada perubahan antara sebelum dan sesudah diberikan terapi kognitif.

Hari ketiga implementasi, responden
1 mengatakan mampu menerapkan terapi kognitif, responden selalu membuat dan membaca buku harian sehingga saat halusinasi muncul mampu menghilangkan pikiran negatifnya dan mencegah halusinasi itu muncul kembali. Frekuensi halusinasi pada hari ketiga berkurang yaitu menjadi $2 x$ selama 24jam, dengan waktu 2x pada siang hari. Dengan demikian ada perubahan antara sebelum dan sesudah diberikan terapi kognitif.

Responden 2 mengatakan hanya sedikit memahami tentang cara penerapan terapi kognitif dan tidak bisa menerapkannya secara mandiri, peneliti harus memberi penjelasan ulang tentang terapi kognitif karena responden pelupa dan sudah memasuki dalam kategori dewasa akhir yang cenderung lambat dalam memahami penjelasan yang diberikan sehingga peneliti harus mengulangi setiap penjelasan untuk lebih memberikan pemahaman pada responden. Frekuensi halusinasi pada hari ketiga tetap sama yaitu menjadi 4x selama 24 jam, dalam waktu siang $2 \mathrm{x}$, sore $1 \mathrm{x}$ dan malam 1x. Dengan demikian masih belum ada perubahan antara sebelum dan sesudah diberikan terapi kognitif..

Saat ditelaah ditemukannya kurangnya data yaitu tidak dicantumkannya respon dari tiap klien mulai pertama kali dilakukan implementasi hari petama hingga hari terakhir (evaluasi formatif). Evaluasi aktivitas dari proses keperawatan dan hasil kualitas dari pelayanan asuhan keperawatan yang diterapkan. Evaluasi proses harus dilakukan segera setelah perencanaan keperawatan dilakukan untuk membantu menilai efektivitas intervensi dan implementasi 
tersebut. Evaluasi proses harus selalu dilakukan hingga tujuan yang telah ditarget itu tercapai (Adinda, 2019).

$\begin{array}{rlr}\text { Pada } & \text { proses } & \text { keperawatan } \\ \text { sebelumnya } & \text { yaitu implementasi } \\ \text { keperawatan } & \text { sudah } & \text { dijabarkan }\end{array}$ tindakan apa saja yang telah dilakukan oleh peneliti. Hasil dari evaluasi dalam asuhan keperawatan adalah tercapainya tujuan/masalah teratasi jika pasien menunjukan perubahan sesuai dengan standar yang ditetapkan. Tujuan yang tercapa sebagian/masalah teratasi sebagian; jika klien menunjukan perubahan sebaian dari standar dan kritaeria yang telah ditetapkan dan tujuan tidak tercapai/ tidak teratasi; jika klien tidak menunjukan perubahan dan kemajuan sama sekali atau bahkan muncul masalah lain (Adinda, 2019)

Evaluasi yang diperoleh peneliti setelah melakukan tindakan implementasi menunjukan pada kasus 1, pasien mampu menerapkan terapi kognitif, frekuensi halusinasi pada ketiga implementasi berkurang menjadi 2x selama 24jam dengan waktu $2 \mathrm{x}$ pada siang hari, pada awalnya pasien mengalami $5 x$ halusinasi selama 24jam, pasien lebih kooperatif dan sudah mau bercerita lebih banyak tanpa ditanya. Jika diamati pada evaluasi hasil maka penulis melakukan evaluasi berdasarkan tujuan yang sudah disampaikan di intervensi, maka bisa diambil kesimpulan bahwa tujuan terapi kognitif untuk mengurangi frekuensi halusinasi pendegaran telah tercapai karena pasien mengatakanmampu menerapkan terapi kognitif.
Pada kasus 2, hasil evaluasi akhir pasien mengatakan hanya sedikit memahami tentang cara penerapan terapi kognitif dan tidak bisa menerapkannya secara mandiri, frekuensi halusinasi ttap sama $4 \mathrm{x}$ selama $24 \mathrm{jam}, 2 \mathrm{x}$ siang, $1 \mathrm{x}$ saat sore dan malam. Jika diamati pada evaluasi hasil maka penulis melakukan evaluasi berdasarkan tujuan yang sudah disampaikan di intervensi, maka bisa diambil kesimpulan bahwa tujuan terapi kognitif untuk mengurangi frekuensi halusinasi pendegaran tidak tercapai karean pasien mengatakan hanya sedikit memahami tentang cara penerapan terapi kognitif dan tidak bisa menerapkannya secara mandiri.

Dari data diatas bisa diambil kesimpulan bahwa penerapan terapi kognitif pada pasien dengan gangguan persepsi sensori : halusinasi pendengaran, keberhasilannya Kembali pada kemampuan masing-masing pasien. Dimana kemampuan pasien Kembali pada situasi kondisi sebelum sakit dipengaruhi banyak hal, salah satunya support system keluarga. Dukungan keluarga adalah tindakan penerimaan keluarga terhadap anggota keluarganya, berupa dukungan informasional, dukungan penilaian, instrumental serta emosional.. Dukungan keluarga emosional yang disini adalah keluarga dapat turut merasakan apa yang pasien rasakan, keluarga tidak merasa malu dengan penyakit yang dialami oleh pasien serta meyakini semua penyakit berasal dari Sang Pencipta (Friedman,2010). Penelitian yang dilakukan Siti (2010) menyebutkan bahwa dukungan emosional keluarga dapat menimbulkan efek penyangga, yaitu 
dukungan keluarga menahan efekefek negatif dari stres terhadap kesehatan yang dialami keluarga dan efek utama yaitu dukungan keluarga secara langsung. Dukungan keluarga secara langsung dapat mempengaruhi peningkatan kesehatan. Dukungan emosional anggota keluarga yang tinggi dapat meningkatkan harga diri serta kemampuan individu dalam mengontrol dirinya. (Andyka, 2018).

\section{SIMPULAN}

A. Pengkajian : Menurut data yang ada, dipastikan bahwa

Responden 1 dan 2 mengalami halusinasi fase ketiga, dimana pada fase ini pasien halusinasi lebih memilih untuk mengikuti arahan yang diberi oleh halusinasinya. Pentingnya penyusunan Analisa data yang kmudian untuk digambarkan dalam pohon masalah.

B. Diagnosa Keperawatan :

Diagnosa halusinasi pendengaran merupakan diagnosa utama pada kedua kasus diatas. Halusinasi pendengaran dapat disebut sebagai diagnose utama karena halusinasi sendiri dapat mengancam rasa aman dan nyaman pasien yang berkaitan dengan hirarki maslow kedua yaitu keamanan dan kenyamanan.

Selain itu ditemukannya diagnosa lain seperti Pada kasus Tn.A Gangguan Persepsi Sensori :Halusinasi Pendengan ,Gangguan Konsep diri : Harga diri rendah, Defisit Perawatan Diri, Isolasi Sosial, Resiko perilaku kekerasan, Ketidefektifan Manajemen Kesehatan, Ketidakpatuhan. Pada kasus Ny.Y Gangguan Persepsi Sensori : Halusinasi Pendengan, Gangguan, Konsep diri : Harga diri rendah, Defisit Perawatan Diri, Isolasi Sosial, Resiko perilaku kekerasan, Ketidefektifan Manajemen Kesehatan, Ketidakpatuhan.

C. Implementasi : Implementasi keperawatan pada ke dua pasien dilakukan selama 4 hari, namun penulis tidak mendapatkan gambaran data respon pasien secara detil karena kurang lengkapnya pendokumentasian untuk evaluasi proses. Evaluasi proses sendiri harus dilakukan segera setelah perencanaan keperawatan dilakukan untuk membantu menilai efektivitas intervensi dan implementasi tersebut. Evaluasi proses harus dilakukan berdasarkan implementasi harian sehingga bisa diketahui tujuan yang telah ditargetkan itu tercapai.

D. Evaluasi

Setelah dilakukan asuhan keperawatan selama 4 hari pada responden 1 dan 2 didapatkan bahwa responden 1 mampu melakukan tindakan terapi kognitif mengalami penurunan frekuensi halusinasi menjadi 2 kali sehari yang awal mulanya 4 kali dalam sehari. Dengan hasil penurunan halusinasi pada Tn.A ditunjukan bahwa Tn.A sudah mampu mencapai kriteria hasil yang ditargetkan pada intervensi yang telah disusun. sedangkan pada responden 2 mengatakan hanya sedikit memahami tentang cara penerapan terapi kognitif, sehingga frekuensi halusinasi yang muncul tetap sama yaitu 4 kali sehari 


\section{SARAN}

A. Bagi keluarga klien dengan halusinasi.

Keluarga yang memiliki anggota dengan halusinasi pendengarah diharapkan dapat memahami dan mengetahui bagaimana cara merawatan anggota keluarga dengan halusinasi pendegaran agar frekuensi halusinasi yang dialami berkurang.

B. Bagi peneliti selanjutnya

Dengan dilakukannya penelitian ini, diharapkan tenaga kesehatan dapat meningkatkan pelayanan kesehatannya dengan cara melakukan terapi kognitif agar prosentase kesembuhan pasien dengan halusinasi pendengaran dapat meningkat.

C. Sebaiknya dalam penyusunan asuhan keperawatan peneliti harus lebih teliti dan mengikuti sesuai dengan kaidah-kaidah asuhan keperawatan yang ada pada Standar Asuhan Keperawatan.

\section{UCAPAN TERIMA KASIH}

Puji syukur kehadirat Allah SWT yang senantiasa telah melmpahkan rahmat, hidayah dan anugrah-Nya sehingga penulis dapat menyusun Karya Tulis Ilmiah karya tulis ilmiah yang berjudul "Gambaran Asuhan Keperawatan Pada Pasien Gangguan Persepsi Sensori ; Halusinasi Pendengaran Dengan Menggunakan Terapi Kognitif".

Karya Tulis Ilmiah Karya Tulis Ilmiah ini merupakan salah satu tahap untuk menyelesaikan pendidikan Diploma III Keperawatan Politeknik Yakpermas Banyumas. Dalam menyusun Karya Tulis Ilmiah ini penulis telah mendapat bantuan dari berbagai pihak baik berupa materi maupun non materi. Oleh karna itu penulis mengucapkan terimakasih kepada beberapa pihak yang telah membantu antara lain :

1. Ibu Rahaju Ningtyas., S.Kp., Mkep selaku Direktur Politeknik Yakpermas Banyumas.

2. Ibu Christina Trisnawati Setiawan, S.Kp.,M,kes selaku dosen pembimbing utama yang telah membimbing penulis dengan baik dan bijaksana sehingga penulis dapat menyelesaikan penyusunan Karya Tulis Ilmiah karya tulis ilmiah ini dan juga bapak Ns. Roni Purnomo, M.Kep yang dengan sabar menuntun saya dalam pembuatan KTI ini.

3. Seluruh dosen dan karyawan Politeknik Yalpermas Banyumas yang telah memberikan fasilitas dan dukungan kepada penulis.

4. Ibu Rahaju Ningtyas., S.Kp., Mkep yang telah membantu, membimbing saya dengan sabar dan memotivasi saya untuk menyelesaikan tugas akhir ini.

5. Ibu saya Sudarwati dan adik saya Mei Lia yang telah memberikan dukungan, doa, semangat, motivasi dan materi kepada penulis sehingga dapat menyelesaikan penulisan KTI.

6. Untuk teman-teman yang telah memberikan dukungan, bantuan, saran dan masukan kepada 
penulis baik di kala sulit maupun senang.

Penulis menyadari bahwa dalam penyusunan dan penulisan Karya Tulis Ilmiah ini banyak kekurangan dan masih jauh dari kata sempurna. Oleh karena itu penulis mengharapkan kritik dan saran yang membangun. Semoga Karya Tulis Ilmiah ini bisa bermanfaat bagi para pembaca dan khususnya bagi penulis.

\section{DAFTAR PUSTAKA}

Adinda, D. (2019). Komponen Dan Jenis-Jenis Evaluasi Dalam Asuhan Keperawatan. https://doi.org/10.31227/osf.io/d ea5u

Andyka, R. (2018). Hubungan Dukungan Keluarga Dengan Kemampuan Pasien Mengontrol Halusinasi Pada Penderita Skizofrenia. $\quad \mathrm{X}(01), \quad 80-90$. http://www.journal.stikeseub.ac. id

AS, A. N. A. (2019). Penerapan Asuhan Keperawatan Pada Pasien Halusinasi Pendengaran Di Ruang Kenanga Rumah Sakit Khusus Daerah Provinsi Sulawesi Selatan. Media Keperawatan: Politeknik Kesehatan Makassar, 10(2), 97. https://doi.org/10.32382/jmk.v1 0i2.1310

Ayuningtyas, D., Misnaniarti, M., \& Rayhani, M. (2018). Analisis Situasi Kesehatan Mental Pada Masyarakat Di Indonesia Dan Strategi Penanggulangannya. Jurnal Ilmu Kesehatan Masyarakat, 9(1), 1-10. https://doi.org/10.26553/jikm.20 18.9.1.1-10
Dalami, E., Suliswati, Farida, P., Rochimah, \& Banon, E. (2009). Asuhan Keperawatan Jiwa dengan Masalah Halusinasi. 134.

Dermawan, D. \& R. (2013). Keperawatan Jiwa: Konsep Dan Kerangka Kerja Asuhan Keperawatan Jiwa (T. Rahayuningsih (ed.); Pertama). Gosyen Publishing. www.gosyenpublishing.web.id

Dharma, K. K. (2013). Metodologi Penelitian Keperawatan (Jusirman (ed.); 11,12). CV.Trans Info Media. www.transinfotim.blogspot.com

FIK UI. (2016). Standar Asuhan Keperawatan Jiwa. Fmipa Ui, 5-34.

HIMPSI. (2020). Terms of Reference: Seri Sumbangan Pemikiran Psikologi untuk Bangsa Ke-5. Himpsi.or.Id, September 2019, 13. https://himpsi.or.id/blog/pengu muman-2/post/kesehatan-jiwadan-resolusi-pascapandemi-diindonesia-panduan-penulisan132

Imron, M. (2014). Metodologi Penelitian Bidang Kesehatan (Aguskomik (ed.); ke-2). Sagung Seto.

Jannah, M. (2019). "Prioritas Masalah Berdasarkan Diagnosa Nanda Untuk Menentukan Intervensi Keperawatan.” https://doi.org/10.31219/osf.io/b xugw

Mislika, M. (2020). Penerapan 
Asuhan Keperawatan Jiwa Pada $\mathrm{Ny}$. N Dengan Halusinasi Pendengaran. 1-35.

Mubin, M. F., Jiwa, K., Universitas, F., Semarang, M., Ners, P. S., Tinggi, S., \& Kesehatan, I. (2019). Hubungan Kepatuhan Minum Obat Dengan Kekambuhan Pasien Skizofrenia Paranoid. Jurnal Farmasetis, 8(1), 21-24. https://doi.org/10.32583/farmas etis.v8i1.493

Noprianti, D. (2019). Penerapan Terapi Kognitif dalam Asuhan Keperawatan Pada Tn.E Dengan Gangguan Persepsi Sensori : Halusinasi Pendengaran di Ruang Cendrawasih Rsj Prof $\mathrm{Hb}$ Saanin.

Pusat Data dan Informasi Kementrian Kesehatan RI. (2019). Situasi Kesehatan Jiwa DI Indonesia. In InfoDATIN (p. 12).

Sandu Siyoto \& M. Ali Sodik. (2015). Dasar Metodologi Penelitian.

Setiawan, R. I. (2017). Asuhan

Keperawatan Jiwa Pada Klien Skizofrenia Simplek Dengan Masalah Gangguan Persepsi Sensori "Halusinasi Pendengaran" Di Ruang Flamboyan Rumah Sakit Jiwa Menur Surabaya.

Sulistyowati, P., \& Purnomo, R. (2021). Asuhan Keperawatan Dengan Pemberian Terapi Musik Pada Pasien Gangguan Persepsi Sensori : Halusinasi Pendengaran Di Ppslu Dewanta
Rpsdm “ Martani ” Cilacap. Asuhan Keperawatan Dengan Pemberian Terapi Musik Pada Pasien Gangguan Persepsi Sensori : Halusinasi Pendengaran Di Ppslu Dewanta Rpsdm “ Martani " Cilacap, Vol. 4 No. 1 (2019): Journal of Nursing and Health, 1-7. https://doi.org/https://doi.org/10 $.52488 /$ jnh.v4i1.39

TRISNO, C. F. (2012). Asuhan Keperawatan Pada Sdr . D Dengan Gangguan Persepsi Sensori : Halusinasi Di Ruang Maespati Rumah Sakit Jiwa Daerah Surakarta. 15.

Wartonah \& Tarwoto. (2006). Kebutuhan Dasar Manusia dan Proses Keperawatan.

Zahnia, S., \& Wulan Sumekar, D. (2016). Kajian Epidemiologis Skizofrenia. Majority, 5(5), 160-166.

http://juke.kedokteran.unila.ac.i d/index.php/majority/article/vie w/904/812 